\title{
A PSTAIRE CDK-like protein localizes in nuclei and cytoplasm of Physarum polycephalum and functions in the mitosis
}

\author{
Gui Ying $\mathrm{LI}^{1,2}$, Miao XING ${ }^{1, *}$, Bo HU ${ }^{1,3}$ \\ ${ }^{1}$ College of Life Science, Shenzhen Key Laboratory of Microbial Gene Engineering, Shenzhen University, Shenzhen 518060, China. \\ ${ }^{2}$ Key Laboratory for Molecular Enzymology and Engineering of Ministry of Education, Jilin University, Changchun 130021, China. \\ ${ }^{3}$ Institute of Genetics and Cytology, Northeast Normal University, Changchun 130024, China.
}

\begin{abstract}
CDKs play key roles in controlling cell cycle progression in all eukaryotes. In plants, multiple CDKs are present, among which the best characterized CDKs are PSTAIRE CDKs. In this study, we carried out Western blot, immunoelectron microscopy and antibody treatment with an anti-PSTAIRE monoclonal antibody to explore the subcellular localization and functions of PSTAIRE CDKs in Physarum polycephalum. The results of Western blot and immunoelectron microscopy showed that in P. polycephalum, a PSTAIRE CDK-like protein was $34 \mathrm{kD}$ in molecular weight and located in both nuclei and cytoplasm. In nuclei, the protein was mainly associated with chromosomes and nucleoli. The expression of the PSTAIRE CDK-like protein in both the plasmodia and nuclei showed little fluctuation through the whole cell cycle. When treated with an anti-PSTAIRE monoclonal antibody at early $\mathrm{S}$ phase, the cells were arrested in S phase, and the mitotic onset of $P$. polycephalum was blocked for about $1 \mathrm{~h}$ when treated at early $\mathrm{G} 2$ phase. Our data indicated that the PSTAIRE CDK- like protein has a direct bearing on the mitosis.
\end{abstract}

Keywords: PSTAIRE CDK-like protein, Physarum polycephalum, mitosis, immunoelectron microscopy.

\section{INTRODUCTION}

The cell cycle in eukaryotic organisms is primarily controlled by cyclin-dependent kinase (CDKs) in complexes with their activating and substrate-specifying partners, cyclins [1]. Based on sequence similarity, plant CDKs can be subdivided into five classes: CDKs A, B, C, D and E [2]. CDK A is the most numerous class. This class comprises CDKs that are most closely related to the prototypical CDKs (i.e., yeast cdc2/CDC28, animal cdc2/CDK1 and CDK2) and contains an evolutionary conserved 16 amino acid sequence called PSTAIRE (EGVPSTAIREISLLKE) motif, which is essential for cyclin binding $[1,2,5,6]$. CDK B makes up a class of plant-specific CDKs which bear their unique motif, either PPTALRE (B1 group) or PPTTLRE (B2 group) and may be involved in the control of the G2/M progression in plants[3]. CDK C (with PITAIRE motif) [2], CDK D (with NFTALRE motif) $[2,4]$ and CDK E (with SPTAIRE motif)[2] form less numerous classes. Currently, CDK A and B are well defined, yet other classes are represented only by one or two known members whose distribution in the plant kingdom remains

${ }^{*}$ Correspondence: Miao XING

E-mail:xingmiao@szu.edu.cn unclear. The best characterized plant CDK belongs to CDK A or PSTAIRE CDKs. PSTAIRE CDKs can partially rescue yeast $\mathrm{cdc} 2 / \mathrm{CDC} 28$ mutations and are therefore supposed to be functional homologs of the yeast $\mathrm{CDKs}$ [3], and play important roles in cell cycle control[1, 5-10]. PSTAIRE CDKs are regulated at several levels, including its expression, differential subcellular localization, phosphorylation, protolysis, and interaction with regulatory proteins. Investigations upon the subcellular localization[11-13] and functions[7-10] of PSTAIRE CDKs have been limited, and opinions on their subcellular location have been divergent [11-13].

Physarum polycephalum is suitable to be used to study the biochemical events in the cell cycle because of its natural synchrony of endomitosis of the plasmodium. Ducommun et al found that cdc2 histone $\mathrm{H} 1$ kinase activity of $P$. polycephalum variated during cell cycle, peaking in metaphase and dropping very abruptly afterwards[14]. Shipley and Sauer identified a homolog of $\mathrm{p} 34^{\mathrm{cdc} 2}$ in $P$. polycephalum and suggested that the homolog was only located in cytoplasm[15]. We previously found, by using monoclonal antibodies against the nonconserved $\mathrm{C}$ terminus of $\mathrm{p} 34^{\text {cdc2 }}$, that a $\mathrm{p} 34^{\text {cdc2 }}$-like protein of $P$. polycephalum situated in both the nucleai and cytoplasm[16]. However, 


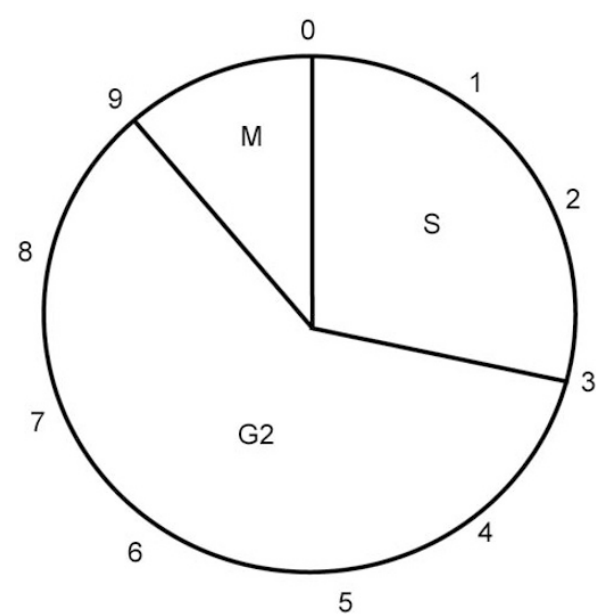

Fig 1. The cell cycle of Physarum polycephalum.

more evidence is needed to elucidate where PSTAIRE CDKs localize in the cell, and what kind of roles they play during the mitosis in P. ploycephalum. In the present study, we carried out Western blot, immunoelectron microscopy and antibody treatment with an anti-PSTAIRE monoclonal antibody to explore the questions above.

\section{MATRIALS AND METHODS}

\section{Materials}

Strain $\mathrm{TU}_{291}$ of Physarum polycephalum, was a gift from Dr. Philipe Albert, Cytobiology laboratory of Reims University, France.

\section{Culture methods}

Suspended and synchronous culture methods of $P$. polycephalum were referred to Denial and Baldwin[17].

\section{Preparation of plasmodial and nuclear specimens}

The cell cycle of $P$. polycephalum consists of $\mathrm{S}, \mathrm{G} 2$, and $\mathrm{M}$ phase, and lacks a G1 phase. The M/S boundary is supposed to be $0 \mathrm{~h}$, and $\mathrm{S}$ phase lasts about $3 \mathrm{~h}$, from 0 to $3^{\text {rd }} \mathrm{h}, \mathrm{G} 2$ phase lasts about $6 \mathrm{~h}$, from $3^{\text {rd }}$ to $9^{\text {th }} \mathrm{h}$, and $\mathrm{M}$ phase lasts about $1 \mathrm{~h}$, from $9^{\text {th }}$ to $10^{\text {th }} \mathrm{h}$ (Fig 1)[18]. By observing the synchronous macroplasmodia under a light microscope, the specimens of S phase $\left(1.5^{\text {st }} h\right)$, early G2 phase $\left(4^{\text {th }} h\right)$, mid G2 phase $\left(6^{\text {th }} h\right)$, late G2 phase $\left(8^{\text {th }} h\right)$, prophase $\left(9^{\text {th }} h\right)$, pre-metaphase, metaphase, and ana-telophase were collected. One half of the plasmodial specimens were directly used for biochemical analyses, and the other half were placed in a pre-cooled solution of nuclei isolation for preparing nuclei specimens according to Mohberg et al[19].

\section{SDS-PAGE and Western blot}

The nuclei specimens at different phases were dissolved in a sample buffer (100 mM Tris $\cdot \mathrm{HCl} \mathrm{pH}$ 6.8, $200 \mathrm{mM}$ DTT, 4\% SDS,

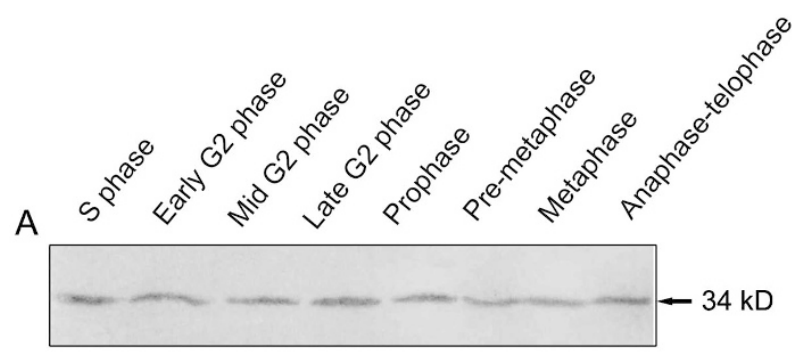

B

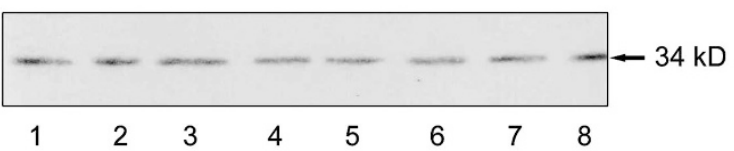

Fig 2. Western blot results of the plasmodia and nuclei proteins at different phases of the cell cycle of Physarum polycephalum. (A) plasmodia; (B) nuclei. A positive band at about $34 \mathrm{kD}$ was detected in plasmodia (A) and nuclei (B) at each phase. The expression of the plasmodia and nuclei specimens at the different phases was consistent.

$0.2 \%$ bromphenol blue, $20 \%$ glycerol) at a dilution of $1: 1$ (in volume). The plasmodia specimens at different phases were dissolved in the same buffer at a ratio of $0.2 \mathrm{~g}$ in wet weight $/ \mathrm{ml}$. $30 \mu \mathrm{l}$ samples lyses per lane were applied to SDS-PAGE using a $10 \%$ polyacrylamide gel. Gels were stained with Coomassie brilliant blue.

For Western blot analysis, the proteins were transferred to the nitrocellulose (NC) membranes after electrophoresis. The membrane was blocked for $1 \mathrm{~h}$ in a blocking buffer ( $2 \%$ non-fat dry milk in PBS buffer, $\mathrm{pH}$ 7.4), and then incubated with anti-PSTAIRE monoclonal antibody (Sigma No. P7962, at a dilution 1:4000 in the blocking buffer) at room temperature for $2 \mathrm{~h}$, washed three times in PBST (0.2\% Tween-20 in PBS buffer, $\mathrm{pH} 7.4$, each for $10 \mathrm{~min})$, incubated with a horseradish peroxidase (HRP)-conjugated sheep anti-mouse IgG secondary antibody (Chinese Biotech Company, at a dilution of $1: 1000$ in the blocking buffer) at room temperature for $2 \mathrm{~h}$, then washed three times in PBST (each for $10 \mathrm{~min}$ ), and stained with diaminobenzidine (DAB).

\section{Immunoelectron microscopy labelling with colloidal gold}

By observing the synchronous macroplasmodia under a light microscope, the specimens of S phase, G2 phase, prophase, metaphase and ana-telophase were collected. The specimens were fixed in a mixture of $2.5 \%$ glutaraldehyde and $4 \%$ paraformaldehyde for $2 \mathrm{~h}$, dehydrated in a grading series of ethanol, and embedded in Lowicryl $\mathrm{K} 4 \mathrm{M}$ resin. Sections were cut on a Reichert-Jung ultromicrotome at a thickness of $60-80 \mathrm{~nm}$, disposed in PBSTT $(0.05 \%$ TritonX-100 and $0.05 \%$ Tween-20 in PBS buffer, $\mathrm{pH} 7.4$ ) at room temperature for $5 \mathrm{~min}$, blocked with $1 \%$ BSA (in PBSTT) for $10 \mathrm{~min}$, and then washed in PBS. After that, the sections were incubated with the antiPSTAIRE monoclonal antibody at a 1:400 dilution in PBS at room temperature for $1 \mathrm{~h}$, washed in PBS and incubated with $10 \mathrm{~nm}$ protein A-colloidal gold (Sigma No. P1039) at a 1:25 dilution in PBS at room temperature for $45 \mathrm{~min}$, washed in PBS and double distilled water, stained with 5\% uranyl acetate for $15 \mathrm{~min}$. After thoroughly washed in double distilled water, the sections were air dried, observed and photographed at $75 \mathrm{kv}$ with a Hitachi-600 transmission electron 
Tab 1. Density of colloidal gold particles in specimens of $P$. polycephalum (Number of particles $\left./ \mu \mathrm{m}^{2}\right)^{*}$

\begin{tabular}{|c|c|c|c|c|c|c|c|}
\hline \multicolumn{2}{|c|}{ Areas } & \multicolumn{5}{|c|}{ Number of specimens } & \multirow{3}{*}{$\begin{array}{c}\mathrm{M} \pm \mathrm{SD} \\
41.97 \pm 0.53\end{array}$} \\
\hline & & \multirow{2}{*}{$\begin{array}{c}1 \\
42.35\end{array}$} & \multirow{2}{*}{$\begin{array}{c}2 \\
40.01\end{array}$} & \multirow{2}{*}{$\begin{array}{c}3 \\
43.21\end{array}$} & \multirow{2}{*}{$\begin{array}{c}4 \\
42.40\end{array}$} & \multirow{2}{*}{$\begin{array}{c}5 \\
41.89\end{array}$} & \\
\hline Interphase & Chromatin & & & & & & \\
\hline & Nucleoli & 39.94 & 41.15 & 39.89 & 42.01 & 41.10 & $40.82 \pm 0.40$ \\
\hline & Nucleoplasm & 14.31 & 12.40 & 13.18 & 12.40 & 13.41 & $13.14 \pm 0.36$ \\
\hline & Nuclei & 24.97 & 23.98 & 24.59 & 24.89 & 24.99 & $24.68 \pm 0.19$ \\
\hline & Cytoplasm & 26.15 & 28.28 & 27.54 & 27.55 & 26.13 & $27.13 \pm 0.43$ \\
\hline & Plasmodia & 25.29 & 25.79 & 25.98 & 26.01 & 25.43 & $25.70 \pm 0.15$ \\
\hline \multirow[t]{6}{*}{ Prophase } & Chromosome & 40.66 & 42.31 & 41.50 & 43.01 & 42.59 & $42.01 \pm 0.42$ \\
\hline & Nucleoli & 40.37 & 40.21 & 40.25 & 41.09 & 40.12 & $40.41 \pm 0.18$ \\
\hline & Nucleoplasm & 5.59 & 2.10 & 6.30 & 11.40 & 10.79 & $7.26 \pm 1.73$ \\
\hline & Nuclei & 25.95 & 23.98 & 24.32 & 24.65 & 24.21 & $24.62 \pm 0.36$ \\
\hline & Cytoplasm & 25.86 & 27.94 & 28.28 & 27.55 & 28.01 & $27.53 \pm 0.43$ \\
\hline & Plasmodia & 25.87 & 25.65 & 25.98 & 26.01 & 25.75 & $25.85 \pm 0.07$ \\
\hline \multirow[t]{5}{*}{ Metaphase } & Chromosome & 42.01 & 40.89 & 42.13 & 41.75 & 41.54 & $41.66 \pm 0.22$ \\
\hline & Nucleoplasm & 19.98 & 20.90 & 19.14 & 20.42 & 19.81 & $20.05 \pm 0.30$ \\
\hline & Nuclei & 25.03 & 25.12 & 24.56 & 24.78 & 24.96 & $24.89 \pm 0.10$ \\
\hline & Cytoplasm & 27.65 & 24.50 & 28.22 & 28.09 & 27.31 & $27.15 \pm 0.68$ \\
\hline & Plasmodia & 25.85 & 24.98 & 25.74 & 25.80 & 25.65 & $25.60 \pm 0.16$ \\
\hline Control & & 0.79 & 1.68 & 1.79 & 1.88 & 2.14 & $1.66 \pm 0.23$ \\
\hline
\end{tabular}

${ }^{*}$ The specimens were embedded in Lowicryl K4M, labeled with anti-PSTAIRE monoclonal antibody and protein A-colloidal gold, observed and photographed with H-600-2 electron microscope. The density of gold particles was obtained by analyses and calculations with IBAS image processing system. For the control group, the labeling with anti-PSTAIRE monoclonal antibody was omitted.

microscope. The density of gold particles was obtained by analyses and calculations with IBAS image processing system.

The samples omitted the treatment of the primary antibody served as controls and were run concurrently with each experiment.

\section{Antibody treatment}

The synchronous macroplasmodia were treated at early $\mathrm{S}$ phase ( 30 min after the last metaphase) and at early G2 phase (about $4^{\text {th }} \mathrm{h}$ ). One half of the synchronous plasmodia was continuously cultured in the conventional MSD media as controls, the other half was transferred and cultured in MSD media containing the anti-PASTIRE antibody (at a 1:4000 dilution in MSD). The cell cycle of the control and the treated plasmodia were observed monitored by light microscopy. The slides were prepared at different points of the cell cycle.

\section{RESULTS}

\section{Western blot analysis of plasmodia and nuclei at different phases of the cell cycle}

The result of Western blot showed that only one specific, positive band was detected at about $34 \mathrm{kD}$ in both plasmodia (Fig 2A) and nuclei specimens (Fig 2B) of S phase, early $\mathrm{G} 2$ phase, mid G2 phase, late $\mathrm{G} 2$ phase, prophase, pre-metaphase, metaphase, and anaphase-telophase, indicating that $P$. polycephalum contained a $34 \mathrm{kD}$ PSTAIRE
CDK-like protein and its expression in both plasmodia and nuclei remained consistent through the cell cycle.

\section{Immunoelectron microscopic localization of PSTAIRE CDK-like protein}

Immunoelectron microscopy showed that the density of the colloidal gold particles of the labeled specimens was significantly higher than that of the control (Tab 1), indicating that the immunolabelling system used in the present study was specific and the gold particles on the specimens marked the position of the PSTAIRE CDK-like protein.

Few gold particles were found on the control specimens (Fig 3A). In labeled specimens, there were a lot of gold particles in the cytoplasm and nuclei (Figs 3B-D). In the interphase nucleus, gold particles were mainly distributed in nucleoli and chromatin areas (Fig 3B). In prophase nucleus, gold particles were mainly distributed in nucleoli and chromosomes (Fig 3C). In the metaphase nuclei, a large number of gold particles were concentrated on chromosomes (Fig 3D). The average density of gold particles in interphase, prophase and metaphase plasmodia (cell) $\left(25.70 / \mu \mathrm{m}^{2}, 25.85\right.$ and $25.60 / \mu \mathrm{m}^{2}$, respectively) was the same on the whole; and that of interphase, prophase and 


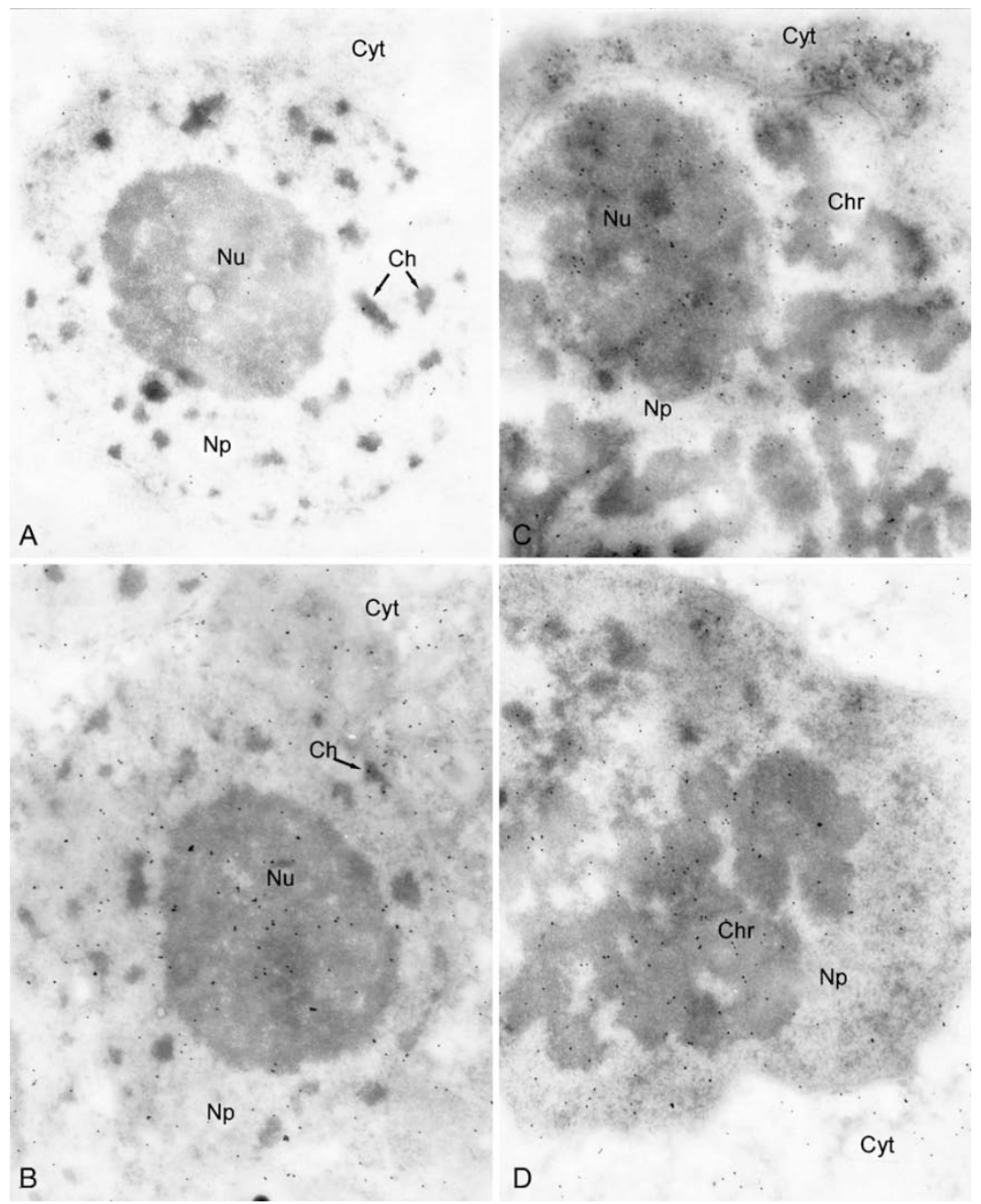

Fig 3. Electron microscopic images of the plasmodia of Physarum polycephalum labeled with anti-PASTIRE antibody and protein A-colloidal gold. (A) Control group, in which the labeling with anti-PSTAIRE monoclonal antibody was omitted. Few gold particles were found on the control specimens. (B) Interphase (G2 phase) plasmodia; (C) Prophase, (D) Metaphase. Many gold particles were distributed in the cytoplasm and nuclei (B, C, D). In the nuclei, gold particles were mainly cocated in nucleoli $(\mathrm{B}, \mathrm{C})$ and the chromatin $(\mathrm{B})$ or chromosomes $(\mathrm{C}, \mathrm{D})$. Cyt: cytoplasm, Nu: nucleoli, Np: nucleoplasm, Chr: chromosomes, Ch: chromatin. $\times 25000$

metaphase nuclei $\left(24.68 / \mu \mathrm{m}^{2}, 24.62\right.$ and $24.89 / \mu \mathrm{m}^{2}$, respectively) was also about the same (Tab 1$)$.

\section{Retardation of the cell cycle by anti-PASTIRE antibody}

The control groups were going on normal endomitosis (Fig 4A-D). In S phase, the chromatin and nucleolar contents mixed together in small nuclei (Fig 4A). In early prophase, the nucleolus was to the side of the nucleus (Fig 4B). In metaphase, chromosomes clusters were aligned on equatorial plate (Fig 4C). In telophase, sister chromatids migrated to different poles, and then two daughter nuclei formed (Fig 4D). However, the cell cycle of the anti-PASTIRE antibody-treated specimens was somewhat inhibited or retarded (Figs 4E-H). In the specimens treated at early $\mathrm{S}$ phase, the cells were arrested in $\mathrm{S}$ phase and cell division was completely prevented (Fig $4 \mathrm{E})$. While in the specimens treated at early G2 phase, the mitotic onset of the cell cycle was blocked for about $1 \mathrm{~h}$, and the mitosis progression was retarded (Figs 4F-H). About $1 \mathrm{~h}$ after the control plasmodia began their M phase, the treated group just entered early prophase (Fig 4F). 


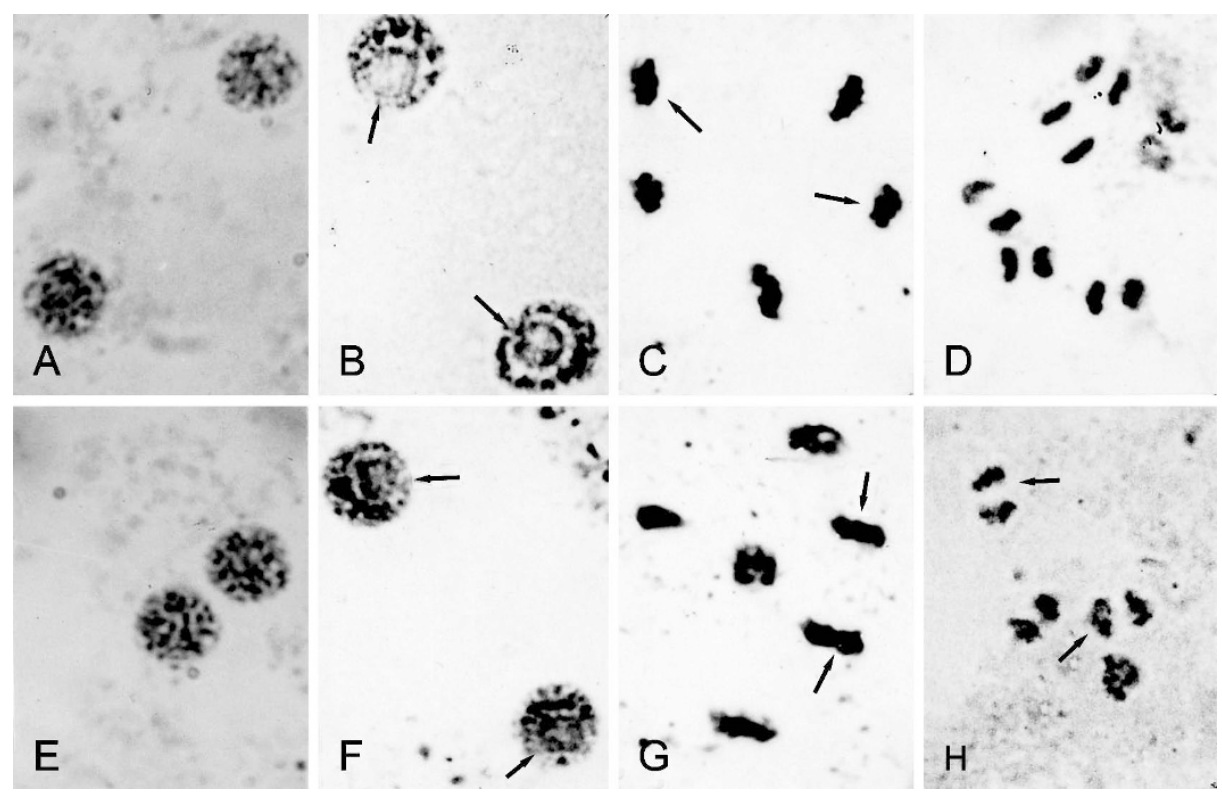

Fig 4. Light microscopic photos showing effects of anti-PSTAIRE antibody treatment upon the cell cycle of Physarum polycephalum. (A-D). Nuclei went on normal mitosis. (E-H) Antibody treated specimens. (E) Nuclei treated with antibody at early S phase and arrested in S phase. (F-H) Nuclei treated at early G2 phase. The mitotic onset of the cell cycle was blocked for about $1 \mathrm{~h}$, and the mitosis progression was retarded. $\times 2000$

When the control plasmodia were in the next cell cycle for about $50 \mathrm{~min}$, the treated plasmodia entered their first metaphase (Fig 4G). When the control was in the next cell cycle for about $60 \mathrm{~min}$, the treated just entered their first telophase (Fig 4H).

\section{DISCUSSION}

CDKs are the central components of eukaryotic cell cycle regulation[1]. In yeast, a single CDK (cdc2 in Schizosaccharomycds pombe or CDC28 in Saccharomyces cerevisiae) governs both the G1/S and G2/M transitions. It contains the PSTAIRE sequence in its cyclin binding domain and binds to different cyclins at different cell cycle stages[1]. In animals, PSTAIRE CDKs include three types, i.e. cdc2/CDK1, CDK2 and CDK3[20-22]. In plants, PSTAIRE CDKs have been identified in several species, such as Arabidopsis (CDC2a), maize (cdc2ZmA), rice (cdc2Os-1 and cdc2Os-2), alfalfa (cdc2MsA and cdc2MsB) and Fucus $[9,10]$. In P. polycephalum, a lower plant often used as an experimental model, Ducommun et al detected cdc2-related activity (histone H1 kinase activity) [14], and Shipley and Sauer found a $34 \mathrm{kD}$ cdc2 homolog by using a peptide antibody directed against a consensus conserved sequence near the N-terminal end of $\mathrm{p} 34^{\mathrm{cdc} 2}$ [15]. In our previous studies, using specific monoclonal antibodies against the nonconserved $\mathrm{C}$ terminus of $\mathrm{p} 34^{\mathrm{cdc} 2}$, we found a p34 ${ }^{\text {cdc2 }}$-like protein in P. polycephalum [16]. In this paper, biochemical and immunoelectron microscopic evidence indicated that $P$. polycephalum contains a PSTAIRE CDK-like protein or CDK A-like protein. This PSTAIRE CDK-like protein and the previously reported p3 $4^{\text {cdc2 }}$-like protein varied little in their molecular weight, expression and subcellular location during the cell cycle, and the cell cycle were retarded by the treatment of the anti-PASTIRE antibody and anti-p34 ${ }^{\text {cdc2 }}$ antibody[16], strongly suggesting that they may be the same protein. The PSTAIRE CDK-like protein reported in this paper and the $34 \mathrm{kD}$ cdc2 homolog identified by Shipley and Sauer [15] share common features, such as molecular weight and content consistence during the cell cycle, suggesting that they also might be the same protein.

A steadily accumulating body of evidence points to the control of subcellular localization of a number of essential proteins, particularly CDC2, cyclinB, cyclinD, CDC25, and CDC6, as an important mechanism of cell cycle control in eukaryote[24]. When assayed by indirect immunofluorescence, PSTAIRE-like CDKs in higher plants (maize, alfalfa, and Arabidopsis) were predominantly found in the interphase and early prophase nucleus, and to a lesser extent in the cytoplasm[11-13]. During mitosis, the PSTAIRE CDKs have been found in association with a number of cytoskeletal structures such as preprophase band, spindle, 
and phragmoplast[11-13]. They also transiently interacted with the chromosomes at the metaphase-anaphase transition in alfalfa[12], but apparently not in maize[13]. In the present study, Western blot and in situ immunoelectron microscopy indicated that the PSTAIRE CDK-like protein of $P$. polycephalum was in both nuclei and cytoplasm throughout the cell cycle, and the protein was mainly associated with nucleoli and chromosomes in the nuclei. The subcellular localization of the PSTAIRE CDK-like protein reported in this paper was different from what was reported in the higher plants[11-13]. The difference possibly results from the differences in the methods and materials used. While the immunofluorescence microscopy was used to localize PSTAIRE CDKs in the previous studies [11-13], we applied immunoelectron microscopy to analyze the subcellular location of the PSTAIRE CDK-like protein at ultrastructural level. So our results may demonstrate the location of the protein more precisely. In addition, $P$. polycephalum is a lower plant. The subcellular localization of PSTAIRE CDK-like proteins in lower plants may be different from the higher ones.

The results of microinjection of anti-p34 $4^{\mathrm{cdc} 2}$ antibodies [25] or $\mathrm{p} 34^{\mathrm{cdc} 2}$ kinase[26] into rat fibroblasts revealed that PSTAIRE CDKs play important roles in animal cell cycle regulation. In plants, however, studies on the function of PSTAIRE CDKs in cell cycle regulation are still rare[1, 710]. Although Hush et al. injected active CDK complexes of metaphase plant cells into Tradescantia stamen hair cells and found rapid disintegration of the preprophase band, nuclear envelope breakdown, and chromosome condensation, the composition of the complexes used in the study was unknown[27]. Recently, Corellou et al injected an anti-PSTAIRE antibody into Fucus zygotes and found that when injected early ( $1 \mathrm{~h}$ after fertilization), anti-PSTAIRE antibody completely prevented cell division and inhibited germination, while when injected at $8 \mathrm{~h}$ after fertilization (i.e. in $\mathrm{S}$ phase), the cell divided and germinated normally [10]. In the present study, the mitosis of $P$. polycephalum was arrested in S phase when treated with anti-PSTAIRE antibody in early $\mathrm{S}$ phase, and the mitotic onset was blocked for about $1 \mathrm{~h}$ when treated with the antibody at early G2 phase. Although the plasmodium of $P$. polycephalum used in the present study was quite different from the Fucus zygotes and the response after the antibody treatments showed some differences, our results were consistent with the results of Corellou et al. in that PSTAIRE CDKs have a direct bearing on the mitosis of plant cells.

\section{ACKOWLEDGEMENTS}

This work was supported by the National Natural Science
Foundation of China (No. 39870389) and the Supported by the Excellent Young Teachers Program of MOE, P. R. C.

Received, Dec 16, 2002

Revised, Dec 14, 2003

Accepted, Dec 29, 2003

\section{REFERENCES}

1 Morgan DO. Cyclin-dependent kinases engines, clocks and microprocessors. Annu Rev Cell Dev Biol 1997; 13:261-91.

2 Joube SJ, Chevalier C, Dudits D. CDK-related protein kinases in plants. Plant Mol Biol 2000; 43(5-6):607-20.

3 Porceddu A, Stals H, Reichheld JP, et al. A plant-specific cyclindependent kinase is involved in the control of $\mathrm{G} 2 / \mathrm{M}$ progression in plants. J Boil Chem 2001; 726(39):36354-60.

4 Fabian-Marwedel T, Umeda M, Sauter M. The rice cyclin-dependent kinase-activating kinase R2 regulates S-phase progression. The plant cell 2002; 14:197-210.

5 Mironov V, de Veylder L, Van Montagu M, Inze D. Cyclindependent kinases and cell division in plants -the nexus. Plant Cell 1999; 11:509-2.

6 Pines J. Cyclins and cyclin-dependent kinases: a biochemical view. Biochem J 1995; 308:697-711.

7 Hemerly A, de Almeida Engler J, Bergounioux C, et al. Dominant negative mutants of the cdc2 kinase uncouple cell division from iterative plant development. EMBO J 1995; 14:3925-36.

8 Healy JMS, Menges M, Doonan JH, Murray JAH. The Arabidopsis D-type cyclins CycD2 and CycD3 both interact in vivo with the PSTAIR cyclin-dependent kinase cdc2a but are differentially controlled. J Biol Chem 2001; 276(10):7041-7.

9 Sorrell DA, Menges M, Healy JM, et al. Cell cycle regulation of cyclin-dependent kinases in tobacco cultivar Bright Yellow-2 cells. Plant Physiol 2001; 126(3):1214-23.

10 Corellou F, Brownlee C, Kloareg B, Bouget FY. Cell cycle-dependent control of polarised deveopment by a cyclin-dependent kinase-like protein in the Fucus zygote. Development 2001; 128: 4383-92.

11 Colasanti J, Cho SO, Wick S, Sundaresan V. Localization of the functional $\mathrm{p} 34^{\text {cdc2 }}$ homolog of maize in root tip and stomatal complex cells: Association wih predicted division sites. Plant Cell 1993; 5:1101-11.

12 Stals H, Bauwens S, Traas J, Van Montagu M, Engler G, Inze D. Plant CDC2 is not only targeted to the preprophase band, but is also co-located with the spindle, phragmoplast and chromosomes. FFBS Lett 1997; 418:229-34.

13 Mews M, Sek FJ, Moore R, Volkmann D, Guning BES, John PCL. Mitotic cyclin distribution during maize cell division: implications for the sequence diversity and function of cyclins in plants. Protoplasma 1997; 200:128-45.

14 Ducommun B, Tollon Y, Gares M, Beach D, Wright M. Cell cycle regulation of $\mathrm{p} 34^{\mathrm{cdc} 2}$ kinase activity in Physarum polycephalum. J Cell Sci 1990; 96:683-9.

15 Shipley GL, Sauer HW. Evidence for a homolog of the yeast cell cycle regulating gene product of $\mathrm{cdc} 2^{+}$in Physarum polycephalum. Eur J Cell Biol 1989; 48:95-103.

$16 \mathrm{Li} \mathrm{GY}$, Xing M, Hu B. P34 ${ }^{\text {cdc2 }}$ - like protein is localized in both nuclei and cytoplasm of Physarum polycephalum. Acta Botanica 
Sinica 2002; 144(8):999-1003.

17 Deniel J W, Baldwin H H. Methods of culture of plasmodial myxomycetes. In: Prescott D M ed. Methods in cell physiol. Academic Press New York 1964; 1(1):9-41

18 Song ZHX, Xing M, Zeng XL. Effects of cytochalasin B upon mitosis of Physarum polycephalum. Acta Genetica Sinica 2000; 27(1):83-9.

19 Mohberg J, Rusch HP. Isolation and DNA content of nuclei of $P$. polycephalum. Exp Cell Res 1971; 66:305-16.

20 Yamashita M, Yoshikuni M, Hirai T, Fukada S, Nagahama Y. A monoclonal antibody against the PSTAIR sequence of $\mathrm{p} 34^{\mathrm{cdc} 2}$, catalytic subunit of maturation-promoting factor and key regulator of the cell cycle. Dev Growth Differ 1991; 33:617-24.

21 Mori M, Yamashita M, Yoshikuni M, Fukada S, Nagahama Y. Maturatio-promoting factor and $\mathrm{p} 34^{\mathrm{cdc} 2}$ kinase during oocytes maturation of the Japanese quail. Dev Biol 1991; 146:246-9.

22 Pines J, Hunter T. Human Cyclins A and B1 differentially and located in the cell and undergo cell cycle-dependent nuclear transport. J Cell Biol 1991; 115(1):1-17.

23 Corellou F, Brownlee C, Detivaud L, Kloareg B, Bouget FY. Cell cycle in the focus zygote parallels a somatic cell cycle but displays a unique translational regulation of cyclin-dependent kinases. Plant Cell 2001; 13(3):585-98.

24 Pines J. Checkpoint on the nuclear frontier. Nature 1999; 397: 104-5.

25 Riabowol K, Draetta G, Brizuela L, Vandre D, Beach D. The cdc2 kinase is a nuclear protein that is essential for mitosis in mammalian cells. Cell 1989; 57:393-401.

26 Lamb NJC, Fernandez A, Watrin A, Labbe JC, Cavadore JC. Microinjectionof $\mathrm{p} 34^{\mathrm{cdc} 2}$ kinase induces marked changes in cell shape, cytoskeleton organization, and chromatin structure in mammalian fibroblasts. Cell 1990; 60(1):151-65.

27 Hush J, Wu L, John PCL, Hepler LH, Hepler PK. Plant mitosis promoting factor disassembles the microtubule preprophase band and accelerates prophase progression in Tradescantia. Cell Biol Int 1996; 20:275-87. 